\title{
REMOVAL OF HEXAVALENT CHROMIUM FROM ELECTROPLATING WASTEWATER BY ELECTROCOAGULATION WITH IRON ELECTRODES
}

\author{
K. DERMENTZIS $S^{1, *}$ \\ A. CHRISTOFORIDIS ${ }^{2}$ \\ E. VALSAMIDOU ${ }^{2}$ \\ A. LAZARIDOU ${ }^{2}$ \\ N. KOKKINOS ${ }^{2}$
}

\author{
${ }^{1}$ Department of Science \\ Laboratory of Chemical Technology and Electrochemistry \\ Technological Education Institute (TEI) of Kavala \\ 65404 Agios Loucas, Kavala, Greece \\ ${ }^{2}$ Department of Petroleum \& Natural Gas Technology \\ Laboratory of Environment Protection \\ Technological Education Institute (TEI) of Kavala \\ 65404 Agios Loucas, Kavala, Greece
}

Received: $15 / 11 / 10$

Accepted: 02/12/11 *to whom all correspondence should be addressed: e-mail: demerz@otenet.gr

\section{ABSTRACT}

The performance of electrocoagulation using iron electrodes for the removal of hexavalent chromium from synthetic aqueous solutions and actual industrial electroplating wastewater was studied. Parameters affecting the electrocoagulation process, such as initial $\mathrm{pH}$, applied current density, initial metal ion concentration, COD and time of electroprocessing were investigated. The optimum $\mathrm{pH}$ was found to be in the range 4-8. Initial chromium concentrations of $200-800 \mathrm{mg} \mathrm{L}^{-1}$ did not influence its removal rate. Higher concentrations were reduced significantly in relatively less time than lower concentrations. Increased current density accelerated the electrocoagulation process, however, on cost of higher energy consumption. Results revealed that best removal was achieved at a current density $40 \mathrm{~mA} \mathrm{~cm}$. The electrocoagulation process was successfully applied to the treatment of an electroplating wastewater sample. Its $\mathrm{Cr}(\mathrm{VI})$ ion concentration and $\mathrm{COD}$ were effectively reduced under the admissible limits in 50 minutes of electroprocessing.

KEYWORDS: electrochemical coagulation, electroplating effluent, hexavalent chromium, iron electrode.

\section{INTRODUCTION}

Heavy metals, such as mercury, lead, chromium, nickel, copper, cadmium and zinc, are of considerable concern because they are non-biodegradable, highly toxic and probably carcinogen. Several treatment processes have been suggested for the removal of heavy metals from aqueous waste streams: adsorption (Lazaridis et al., 2005), biosorption (Senthikumar et al., 2010), ion exchange (Inglezakis et al., 2003), chemical precipitation (Kurniawan et al., 2006) and electrochemical methods: electrowinning (Bolger and Szlag, 2004), electrodialysis (Marder et al., 2004), electrodeionization (Yeon et al., 2003; Lu et al., 2010), membrane-less electrostatic shielding electrodialysis/electrodeionization Dermentzis et al., 2010) and electrocoagulation.

Chromium is released into the environment from electroplating, anodizing, chromating, metal finishing, tannery, dying and fertilizer industries (Liu et al., 2011; Vasudevan et al., 2010). Waste streams from electroplating units may contain up to $2500 \mathrm{mg} \mathrm{L}^{-1} \mathrm{Cr}(\mathrm{VI})$, which according to environmental regulations worldwide must be controlled to an acceptable level before being discharged to the environment. The permissible limits for $\mathrm{Cr}(\mathrm{VI})$ is $0.5 \mathrm{mg} \mathrm{L}^{-1}$ in effluent discharge to sewage systems and $0.1 \mathrm{mg} \mathrm{L}^{-1}$ in drinking water.

The most common and economical method for hexavalent chromium removal involves reduction to its trivalent state and subsequent precipitation with alkali. As reducing agents are used ferrous ions, sulfur dioxide, sodium bisulfite or hydrazinium salts. The reduced trivalent chromium is then precipitated by addition of an alkali e.g. lime or caustic soda according to reactions (1), (2) and (3): 


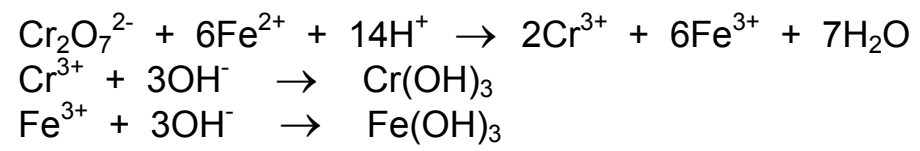

The produced sludge amount in the above process is very large, since for $1 \mathrm{~kg}$ of chromium removed $32 \mathrm{~kg}$ of sludge is generated, which is difficult to handle (Reddithota et al., 2007).

Chemical coagulation is a quite effective method for treating heavy metal bearing wastewaters but may induce secondary pollution by adding coagulants, such as aluminum or iron salts or organic polyelectrolytes to remove colloidal matter as gelatinous hydroxides. Also this wastewater treatment process produces a large amount of sludge.

Electrochemical coagulation or otherwise called electrocoagulation uses no chemicals as coagulating agents. These are generated during the electrolysis process by electrodissolution of a sacrificial anode made of aluminum or iron. Electrocoagulation has been successfully performed for treatment and remediation of textile wastewaters (Dermentzis et al., 2011; Kobya et al., 2003; Raju et al., 2008), oil wastes (Abdelwahab et al., 2009; Un et al., 2009), diary effluents (Tchamango et al., 2010), diesel and bio-diesel wastewaters (Chavalparit \& Ongwandee, 2009; El-Naas et al., 2009), laundry wastewaters (Wang et al., 2009), slaughter house effluents (Asselin et al., 2008), arsenic or fluoride containing waters (Hansen et al., 2007; Hu et al., 2008) and heavy metal bearing effluents (Adhoum et al., 2004; Heidmann \& Calmano 2008; Kongsricharoern \& Polprasert, 1996; Nouri et al., 2010).

The objective of this paper was to investigate the efficiency of electrocoagulation in removing hexavalent chromium from synthetic aqueous solutions and actual industrial wastewater. In addition, the effect of $\mathrm{pH}$, current density, initial metal concentration, time of electroprocessing and COD was investigated.

\section{METHODS}

\subsection{Chemicals}

$\mathrm{KCl}, \mathrm{K}_{2} \mathrm{Cr}_{2} \mathrm{O}_{7}$ and $\mathrm{NaOH}$ were of analytical grade (Merck). $\mathrm{pH}$ was adjusted by $0.1 \mathrm{M}$ solutions of $\mathrm{HCl}$ and $\mathrm{NaOH}$ as required. The actual wastewater was obtained from an electroplating unit located near Thessaloniki, northern Greece.

\subsection{Apparatus}

A laboratory model DC power supply apparatus (PHYWE Systeme $\mathrm{GmbH} \& \mathrm{Co}$.) was used to maintain constant DC current. Voltage and current were measured by a multimeter (PHYWE). Conductivity was measured by means of a conductometer (WTW). $\mathrm{pH}$ and temperature were measured using a Hanna $\mathrm{pH}$-meter connected to a combined electrode comprising a temperature sensor.

The chemical oxygen demand (COD) was analyzed using a COD reactor (Thermoreaktor TR 420, MERCK) and a direct reading spectrophotometer (Spectroquant Pharo100, MERCK).

Electrochemical experiments were conducted at room temperature in a cylindrical glass cell of 400 $\mathrm{ml}$ in which aliquot solutions of $200 \mathrm{~mL}$ were placed and slowly stirred with a magnetic bar at 500 $\mathrm{rpm}$. Two commercially obtained iron plates were used as electrodes with size $10 \mathrm{~cm} \times 5 \mathrm{~cm} \times 0.2 \mathrm{~cm}$ immersed to a $6 \mathrm{~cm}$ depth with an effective area of $30 \mathrm{~cm}^{2}$ each. The interelectrode distance was $1.5 \mathrm{~cm}$. To remove the oxide and passivation layer from iron surface the electrodes were grinded with sandpaper and energized by dipping them in $\mathrm{HCl} 5 \mathrm{~N}$ for 1 minute. $0.5 \mathrm{~g} \mathrm{KCl}$ was added to every treated solution. The added $\mathrm{KCl}$ served for prevention of passivation on the iron electrode surface and decrease of the excessive ohmic drop in the solution. The polarity of the cell was reversed every 30 minutes to limit the formation of the passivation layers on the electrodes.

Samples were extracted every 10 minutes, filtered using Whatman filter paper (Grade 40). The residual chromium concentrations were determined by Atomic Absorption Spectroscopy AAS (Perkin Elmer 5100). At the end of each experiment the produced sludge was measured. 


\subsection{Brief description of electrocoagulation}

Electrocoagulation is a process consisting of creating metallic hydroxid flocs inside the wastewater by electrodissolution of soluble anodes made of aluminum or iron. The electrochemical oxidation of iron anodes produces ferrous, $\mathrm{Fe}^{2+}$ and ferric, $\mathrm{Fe}^{3+}$ ions. The $\mathrm{Fe}^{2+}$ ions can reduce $\mathrm{Cr}(\mathrm{VI})$ to $\mathrm{Cr}$ (III) in alkaline to neutral medium, while they are oxidized to $\mathrm{Fe}^{3+}$ ions according to reaction (4):

$\mathrm{CrO}_{4}{ }^{2-}+3 \mathrm{Fe}^{2+}+4 \mathrm{H}_{2} \mathrm{O}+4 \mathrm{OH}^{-} \rightarrow 3 \mathrm{Fe}(\mathrm{OH})_{3}+\mathrm{Cr}(\mathrm{OH})_{3}$

Both, $\mathrm{Fe}^{3+}$ and $\mathrm{Cr}^{3+}$ ions combine with the generated $\mathrm{OH}$ - ions and precipitate as insoluble hydroxides. The $\mathrm{Fe}^{2+}$ ions can also reduce $\mathrm{Cr}_{2} \mathrm{O}_{7}{ }^{2-}$ ions in acidic medium according to reaction (1), as already stated. The generated $\mathrm{H}_{2}$ gas produced at the cathode can remove dissolved organics or any suspended material by flotation. Furthermore, $\mathrm{Fe}^{3+}$ ions undergo hydration and give, depending on $\mathrm{pH}$, cationic species such as $\mathrm{Fe}(\mathrm{OH})^{2+}, \mathrm{Fe}(\mathrm{OH})_{2}{ }^{2+}$ in acidic conditions, $\mathrm{Fe}(\mathrm{OH})_{3}$ in neutral conditions and anionic species such as $\mathrm{Fe}(\mathrm{OH})_{4}{ }^{-}, \mathrm{Fe}(\mathrm{OH})_{6}{ }^{3-}$ in alkaline conditions which finally result in situ formation of gelatinous $\mathrm{Fe}(\mathrm{OH})_{3}$ effecting the coagulation and co-precipitation from the solution by adsorption. The iron hydroxide flocs act as adsorbents for heavy metal ions. Furthermore, heavy metal ions combine with the electro-generated $\mathrm{OH}^{-}$ions at the cathode and precipitate in form of their insoluble hydroxides. Both phenomena act synergistically leading to a rapid removal of heavy metal pollutants from water. $\mathrm{Fe}^{3+}$ as a flocculation agent is advantageous, due to its innocuity compared to $\mathrm{Al}^{3+}$, which shows some toxic effects.

\section{RESULTS AND DISCUSSION}

\subsection{Effects of operating parameters}

The electrocoagulation process is affected by several operating parameters, such as initial $\mathrm{pH}$, pollutants concentration, applied current density, COD and contact time. In the present study all these have been explored in order to evaluate a treatment technology for chromium removal from synthetic solutions and actual electroplating wastewaters.

\subsubsection{Initial $\mathrm{pH}$}

$\mathrm{pH}$ has a considerable effect on the efficiency of the electrocoagulation process. In addition, $\mathrm{pH}$ changes during the process dependent on the anode material and the initial $\mathrm{pH}$ value of the treated solution. The increase of $\mathrm{pH}$ at initial $\mathrm{pH}$ lower than 7 is ascribed to the hydrogen evolution and the generation of $\mathrm{OH}^{-}$ions at the cathodes (Vik et al., 1984). In alkaline medium $(\mathrm{pH}>8)$ the final $\mathrm{pH}$ does not change markedly because the generated $\mathrm{OH}^{-}$ions at the cathodes are consumed by the generated $\mathrm{Fe}^{3+}$ ions at the anode forming the needed $\mathrm{Fe}(\mathrm{OH})_{3}$ flocs. Furthermore, $\mathrm{OH}^{-}$ions can also partially combine with $\mathrm{Cr}^{3+}$ ions to form the insoluble hydroxide precipitate $\mathrm{Cr}(\mathrm{OH})_{3}$.

Experiments conducted at different initial $\mathrm{pH}$ values in the range 1-10 showed that the removal percent of chromium is low at $\mathrm{pH}<2$. It increases considerably at $\mathrm{pH} 4$, remains high and almost constant in the $\mathrm{pH}$ range $4-8$ and substantially decreases at $\mathrm{pH}>8$. The decrease in removal efficiency at strong acidic and strong alkaline $\mathrm{pH}$ was described by other researchers (Adhoum et al., 2004; Vasudevan et al. 2009). It was ascribed to an amphoteric behavior of $\mathrm{Fe}(\mathrm{OH})_{3}$ which leads to soluble cations $\mathrm{Fe}^{3+}, \mathrm{Fe}(\mathrm{OH})^{2+}, \mathrm{Fe}(\mathrm{OH})_{2}^{+}$(at acidic $\mathrm{pH}$ ) and to monomeric anions $\mathrm{Fe}(\mathrm{OH})_{4}^{-}$, $\mathrm{Fe}(\mathrm{OH})_{6}^{3-}$ (at alkaline $\left.\mathrm{pH}\right)$. It is well known that these species are not usefull for water treatment. For these reasons the electrocoagulation process was conducted in the $\mathrm{pH}$ range 4-8.

\subsubsection{Current density}

Khosla et al. (1991) reported that the applied current density determines the coagulant dosage rate, the bubble production rate and size and the flocs growth resulting in a faster removal of pollutants. Measurements were carried out at different current densities $10-40 \mathrm{~mA} \mathrm{~cm}{ }^{-2}$, at a constant heavy metal concentration of $800 \mathrm{mg} \mathrm{L}^{-1}$ and initial $\mathrm{pH} 7.5$. According to Fig. 1 the removal rate of chromium increased, as expected, with increasing current density. After 40 minutes of electrolysis time at the current density $40 \mathrm{~mA} \mathrm{~cm}^{-2}, \mathrm{Cr}(\mathrm{VI})$ ions have been almost quantitatively removed $(>99 \%)$ and their concentration decreased under the admissible limits for effluents discharge to sewage systems $\left(0.5 \mathrm{mg} \mathrm{L}^{-1}\right)$. 


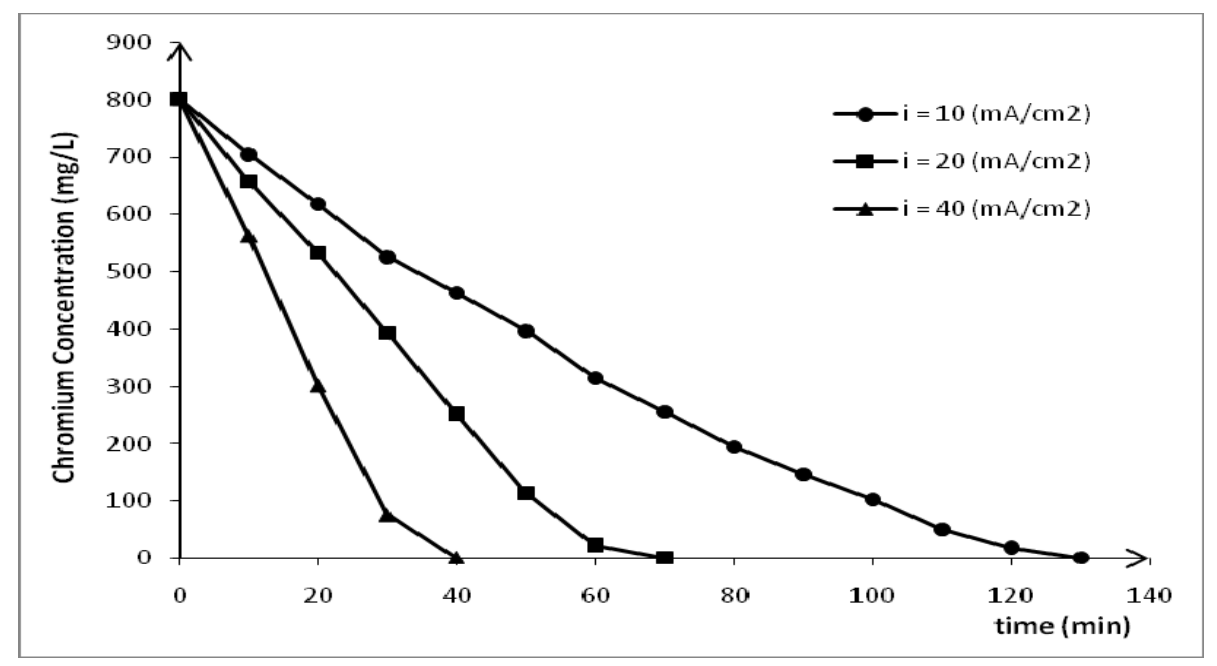

Figure 1. Chromium concentration versus time at different current densities

$\mathrm{Cr}(\mathrm{VI})$ ions must first be reduced to $\mathrm{Cr}$ (III) ions at the cathode, according to reaction (5), which then combine with the generated $\mathrm{OH}^{-}$ions and precipitate as insoluble $\mathrm{Cr}(\mathrm{OH})_{3}$ or are adsorbed to the $\mathrm{Fe}(\mathrm{OH})_{3}$ flocs.

$\mathrm{Cr}_{2} \mathrm{O}_{7}{ }^{2-}+6 \mathrm{e}^{-}+7 \mathrm{H}_{2} \mathrm{O} \rightarrow 3 \mathrm{Cr}^{3+}+14 \mathrm{OH}^{-}$

Furthermore, $\mathrm{Cr}(\mathrm{VI})$ ions can also be reduced to $\mathrm{Cr}$ (III) ions by $\mathrm{Fe}$ (II) ions which in turn are oxidized to $\mathrm{Fe}$ (III) ions according the reaction (1) in acidic $\mathrm{pH}$ or according to reaction (4) in alkaline to neutral $\mathrm{pH}$, as already stated in the introductory section 1 and 2.3 respectively. The presence of ferrous ions enhances the reduction and removal of chromium. Consequently, the removal rate of chromium by electrocoagulation with iron electrodes is faster compared to that with aluminium electrodes.

\subsubsection{Initial metal ion concentration}

To demonstrate the effect of initial metallic pollutant concentration and the time required for its quantitative removal, a set of experiments was conducted with different initial concentrations 200, 400 and $800 \mathrm{mg} \mathrm{L}^{-1}$ of chromium ions. Each solution was treated at a constant current density of 40 $\mathrm{mA} \mathrm{cm} \mathrm{cm}^{-2}$ and different times of electrolysis.

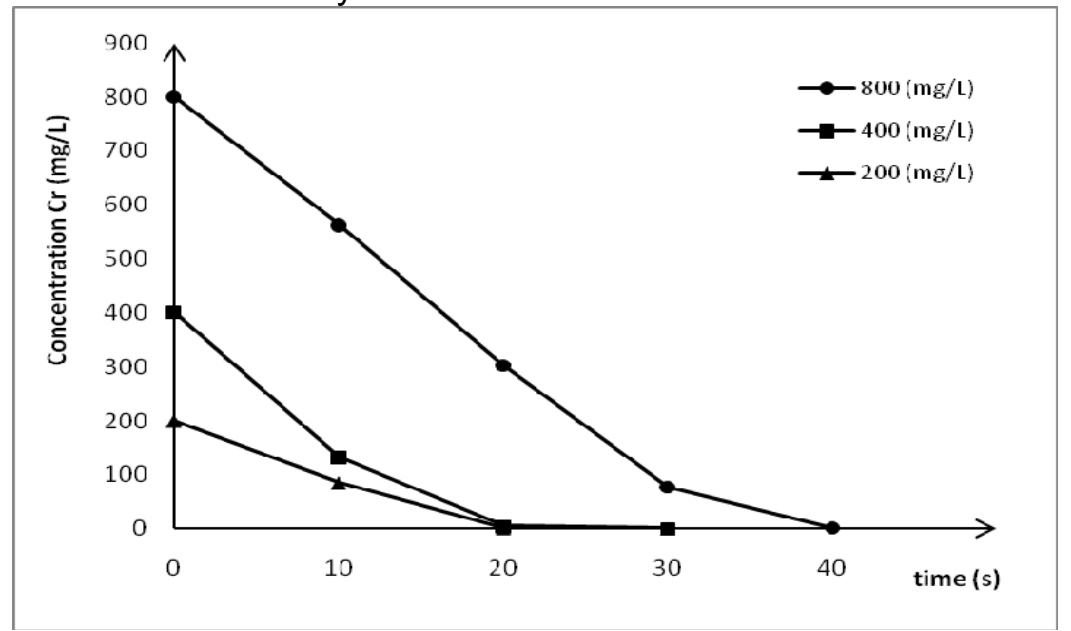

Figure 2. Effect of initial concentration of chromium on its removal efficiency versus time

Fig. 2 shows the variations of the different initial concentrations of chromium and its removal efficiency with time. The three chromium ion concentrations were reduced to admissible levels in 20 , 25 and 40 minutes respectively. According to Fig. 2, no direct correlation exists between metal ion concentration and removal efficiency. Certainly, for higher concentrations longer time for removal is 
needed, but higher initial concentrations were reduced significantly in relatively less time than lower concentrations. The electrocoagulation process is more effective at the beginning when the concentration is higher than at the end of the operation when the concentration is low.

\subsection{Treatment of actual wastewaters}

The applicability of the electrocoagulation process for actual wastewater was validated by treating an industrial effluent sample, collected from an electroplating unit. As known, chromium electrodeposits are mainly obtained from acidic hexavalent chromium electrolytic baths. During the plating process $\mathrm{Cr}(\mathrm{VI})$ ions contaminate the rinse waters when the plated objects are rinsed upon removal from the plating bath.

At a constant current density of $40 \mathrm{~mA} \mathrm{~cm} \mathrm{~cm}^{-2}$ and an electrolysis time of 50 minutes the concentration of chromium decreased under the admissible limits (Fig. 3). The removal efficiency re is very high $(99.9 \%)$. It is calculated from the formula of equation 1 :

$$
r e=\frac{C_{o}-C}{C_{o}} \times 100
$$

where $C_{o}$ and $C$ are the initial and final concentrations of chromium ions in the treated wastewater.

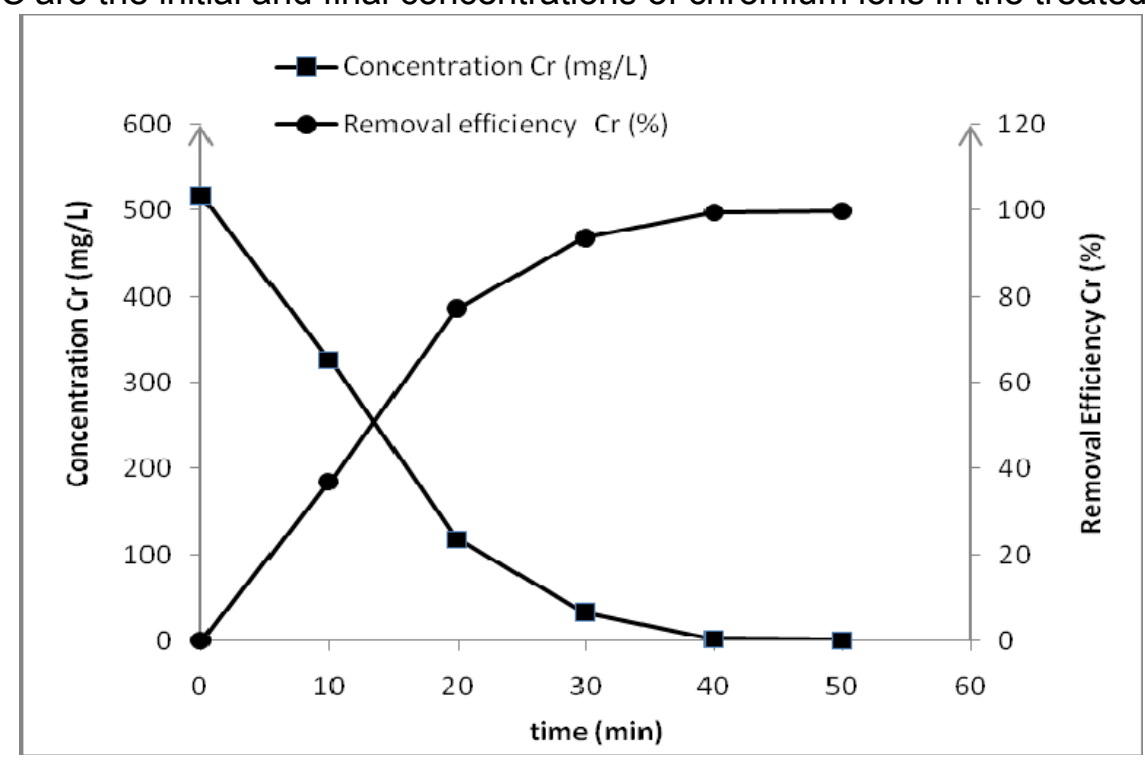

Figure 3. Concentration variation and removal efficiency of chromium versus time during the electrocoagulation treatment of the electroplating wastewater

Compared to the removal from synthetic solutions (Figs 1,2 ) the removal rate of chromium from actual wastewater seems to be slower. This should be attributed to the presence of the organic compounds, which also compete for adsorption on the $\mathrm{Fe}(\mathrm{OH})_{3}$ flocs resulting in a substantial reduction of the metal ions removal. The initial COD content of $530 \mathrm{mg} \mathrm{L}^{-1}$ decreased to $183 \mathrm{mg} \mathrm{L}^{-1}$ after 50 minutes of electroprocessing showing a removal efficiency of about $65.5 \%$. During the electrocoagulation treatment of the wastewater its initial $\mathrm{pH}$ value of 3.5 rose to a final value of 8.4 .

\subsection{Electrode mass loss and energy consumption}

The costs in wastewater treatment with electrocoagulation are the expenditure on mass loss of electrodes and the electrical energy consumption. The mass loss of the iron anode $m_{F e}$ can be calculated from equation (2) using the Faraday's law:

$$
m F e=\frac{I \cdot t \cdot M}{Z \cdot F \cdot V}
$$

where

$$
\begin{aligned}
& I=\text { current intensity }(\mathrm{A}) \\
& t=\text { time }(\mathrm{s}) \\
& M=\text { Molecular weight of iron }\left(\mathrm{g} \mathrm{mol}^{-1}\right)
\end{aligned}
$$


$z=$ number of electrons transferred in the reaction $\mathrm{Fe} \rightarrow \mathrm{Fe}^{2+}+2 \mathrm{e}^{-}$

$F=$ Faraday's constant $\left(96500 \mathrm{Cb} \mathrm{mol}^{-1}\right)$

$V=$ wastewater solution volume.

Under the given operating conditions the mass loss of the sacrificial iron anode per liter of the treated wastewater is $4.34 \mathrm{~g} \mathrm{Fe} \mathrm{L}^{-1}$.

Similarly, the electrical energy consumption $E$ is calculated from equation (3):

$E=\frac{U \cdot I \cdot t}{V}$

Where: $U=$ voltage (Volts).

The energy consumption amounts to $0.046 \mathrm{kWh} \mathrm{L}^{-1}$ of treated wastewater.

\subsection{Sludge characteristics}

The precipitated sludge was collected, dried at $103{ }^{\circ} \mathrm{C}$ for $24 \mathrm{~h}$, cooled in a desiccator and weighed. Its amount was determined by the Faraday's law. Compared to the conventional chemical precipitation - coagulation process, electrocoagulation produces apparently lower amount of sludge.

\section{CONCLUSIONS}

Electrocoagulation with iron electrodes is a safe, reliable, convenient and efficient route for removal of heavy metals, such as chromium and COD from water and industrial wastewater. Best removal efficiency was achieved in the $\mathrm{pH}$ range 4-8. Removal rate increased with increasing current density. Initial chromium concentration of $200,400,800 \mathrm{mg} \mathrm{L}^{-1}$ in synthetic solutions and $517 \mathrm{mg} \mathrm{L}^{-1}$ in industrial wastewater at a current density of $40 \mathrm{~mA} \mathrm{~cm}$ reduced under the admissible limits in a short period of time. Furthermore, the COD in electroplating wastewater was also removed. In comparison to chemical coagulation, where an increased coagulant dosage and several hours are needed, electrocoagulation is a faster and more economical method for wastewater treatment.

\section{REFERENCES}

Abdelwahab O., Amin N.K. and El-Ashtoukhy E-S.Z. (2009), Electrochemical removal of phenol from oil refinery wastewater, Journal of Hazardous Materials, 163, 711-716.

Adhoum N., Monser L., Bellakhal N. and Belgaied J-E. (2004), Treatment of electroplating wastewater containing $\mathrm{Cu}^{2+}, \mathrm{Zn}^{2+}$ and $\mathrm{Cr}(\mathrm{VI})$ by electrocoagulation, Journal of Hazardous Materials, B112, 207213.

Asselin M., Drogui P., Benmoussa H. and Blais J-F. (2008), Effectiveness of electrocoagulation process in removing organic compounds from slaughterhouse wastewater using monopolar and bipolar electrolytic cells, Chemosphere, 72, 1727-1733.

Bolger P.T. and Szlag D.C. (2004), Electrochemical treatment and reuse of nickel plating rinse waters, Environmental Progress, 21, 203-208.

Chavalparit O. and Ongwandee M. (2009), Optimizing electrocoagulation process for the treatment of biodiesel wastewater using response surface methodology, Journal of Environmental Sciences, 21,1491-1496.

Dermentzis K.I., Davidis A.E., Dermentzi A.S. and Chatzichristou C.D. (2010), An electrostatic shielding based coupled electrodialysis / electrodeionization process for removal of cobalt ions from aqueous solutions, Water Science and Technology, 62, 1947-53.

Dermentzis K., Marmanis D., Valsamidou E., Christoforidis A. and Ouzounis K. (2011), Electrochemical decolorization treatment of nickel phthalocyanine reactive dye wastewater, Environmental Engineering and Management Journal, 10, 1703-1709.

El-Naas M.H., Al-Zuhair S., Al-Lobaney A. and Makhlouf S. (2009), Assessment of electrocoagulation for the treatment of petroleum refinery wastewater, Journal of Environmental Management, 91, 180-185.

Hansen H.K., Nunez P., Raboy D., Schippacase I. and Grandon R. (2007), Electrocoagulation in wastewater containing arsenic: Comparing different process designs, Electrochimica Acta, 52, 34643470.

Heidmann I. and Calmano W. (2008), Removal of $\mathrm{Zn}(\mathrm{II}), \mathrm{Cu}(\mathrm{II}), \mathrm{Ni}(\mathrm{II}), \mathrm{Ag}(\mathrm{I})$ and $\mathrm{Cr}(\mathrm{VI})$ present in aqueous solutions by aluminium electrocoagulation, Journal of Hazardous Materials, 152, 934-941. 
Hu C-Y., Lo S-L., Kuan W.H. and Lee Y.D. (2008), Treatment of high fluoride-content wastewater by continuous electrocoagulation-flotation system with bipolar aluminium electrodes, Separation and Purification Technology, 60, 1-5.

Inglezakis V.J., Loizidou M.D. and Grigoropoulou H.P. (2003), lon exchange of $\mathrm{Pb}^{2+}, \mathrm{Cu}^{2+}, \mathrm{Fe}^{3+}$ and $\mathrm{Cr}^{3+}$ on natural clinoptilolite: selectivity determination and influence on activity on metal uptake, Journal of Colloid and Interface Science, 261, 49-54.

Kobya M., Can O.T. and Bayramoglu M. (2003), Treatment of textile wastewaters by electrocoagulation using iron and aluminium electrodes, Journal of Hazardous Materials, B100, 163-178.

Kongsricharoern N. and Polprasert C. (1996), Chromium removal by bipolar electro-chemical precipitation process, Water Science and Technology, 34, 109-116.

Khosla N.K., Venkachalam S. and Sonrasundaram P. (1991), Pulsed electrogeneration of bubbles for electroflotation, Journal of Applied Electrochemistry, 21, 986-990.

Kurniawan A., Chan G.Y.S., Lo W-H. and Babel S. (2006), Physico-chemical treatment techniques for wastewater laden with heavy metals, Chemical Engineering Journal, 118, 83-98.

Lazaridis N.K., Bakayannakis D.N. and Deliyianni E.A. (2005), Chromium (VI) sorptive removal from aqueous solution by nano crystalline akaganeite, Chemosphere, 58, 65-73.

Liu Y-X, Yuan D-X, Yan J-M, Li Q-L and Ouyang T. (2011), Electrochemical removal of chromium from aqueous solutions using electrodes of stainless steel nets coated with single wall carbon nanotubes, Journal of Hazardous Materials, 186, 473-480.

Lu H., Wang J., Yan B. and Bu S. (2010), Recovery of nickel ions from simulated electroplating rinse water by electrodeionization process, Water Science and Technology, 61, 729-35.

Marder L., Bernardes A.M. and Ferreira J.Z. (2004), Cadmium electroplating wastewater treatment using a laboratory-scale electrodialysis system, Separation and Purification Technology, 37, 247-255.

Nouri J., Mahvi A.H. and Bazrafshan E. (2010), Application of electrocoagulation process in removal of zinc and copper from aqueous solutions by aluminum electrodes, International Journal of Environmental Research, 4, 201-208.

Raju G.B., Karuppiah M.T., Latha S.S., Parvathy S. and Prabhakar S. (2008), Treatment of wastewater from synthetic textile industry by electrocoagulation-electrooxidation, Chemical Engineering Journal, $144,51-58$.

Reddithota D., Yerramilli A. and Krupadarm R.J. (2007), Elrctrocoagulation: A cleaner method for treatment $\mathrm{Cr}(\mathrm{VI})$ from electroplating industrial effluents, Indian Journal of Chemical Technology, 14, 140-245.

Senthikumar R., Vijaraghavan K., Jegan J. and Velan M. (2010), Batch and column removal of total chromium from aqueous solution using Sargassum polycystum, Environmental Progress and Sustainable Energy, 29, 334-341.

Tchamango S., Nanseu-Njiki C.P., Ngameni E., Hadjiev D. and Darchen A. (2010), Treatment of dairy effluents by electrocoagulation using aluminium electrodes, Science of the Total Environment, 408, 947-952.

Un U.T., Koparal A.S. and Ogutveren U.B. (2009), Electrocoagulation of vegetable oil refinery wastewater using aluminium electrodes, Journal of Environmental Management, 90, 428-433.

Vasudevan S., Lakshmi J. and Sozhan G. (2009), Studies on the removal of iron from drinking water by electrocoagulation - A clean process, Clean-Soil, Air, Water, 37, 45-51.

Vasudevan S., Lakshmi J. and Vanathi R. (2010), Electrochemical coagulation for chromium removal: process optimization, kinetics, isotherms and sludge characterization, Clean-Soil, Air, Water, 38, 916.

Vik E.A., Carlson D.A., Eikum A.S. and Gjessing E.T. (1984), Electrocoagulation of potable water, Water Research, 18, 1355-1360.

Wang C-T., Chou W-L. and Kuo Y-M. (2009), Removal of COD from laundry wastewater by electrocoagulation/electroflotation, Journal of Hazardous Materials, 164, 81-86.

Yeon K.H., Seong J.H., Rengaraj S. and Moon S.H. (2003), Electrochemical characterization of ionexchange resin beds and removal of cobalt by electrodeionization for high purity water production, Separation Science and Technology, 38, 443-462. 